Rowley, M. G., R. C. Stanley, J. M. Antalffy, J. L. Christhilf, D. C. Stonko, S. B. Johnson, S. Cant-Woodside, T. Scott Sillett, M. E. Fagan, C. E. Studds, and K. E. Omland. 2021. Hierarchical distance sampling reveals increased population size and broader habitat use in the endangered Bahama Oriole. Avian Conservation and Ecology 16(1):5. https://doi.org/10.5751/ACE-01775-160105

Copyright (C) 2021 by the author(s). Published here under license by the Resilience Alliance.

Research Paper

\title{
Hierarchical distance sampling reveals increased population size and broader habitat use in the endangered Bahama Oriole
}

\author{
Michael G. Rowley ${ }^{1}$, Richard C. Stanley ${ }^{2}$, Janine M. Antalffy ${ }^{1}$, Jennifer L. Christhilf ${ }^{3}$, Daniel C. Stonko ${ }^{1}$, Scott B. Johnson ${ }^{4}$, \\ Shelley Cant-Woodside ${ }^{4}$, T Scott Sillett ${ }^{5}$, Matthew E. Fagan ${ }^{3}$, Colin E. Studds ${ }^{3}$ and Kevin E. Omland ${ }^{1}$ \\ ${ }^{1}$ University of Maryland, Baltimore County (UMBC), Biological Sciences, ${ }^{2}$ University of Florida, School of Natural Resources \\ and Environment, ${ }^{3}$ University of Maryland, Baltimore County (UMBC), Geography and Environmental Systems, ${ }^{4}$ Bahamas \\ National Trust, ${ }^{5}$ Smithsonian Conservation Biology Institute
}

\begin{abstract}
The Caribbean is home to over 20 passerine species listed by the International Union for Conservation of Nature as vulnerable, endangered or critically endangered. The Bahama Oriole (Icterus northropi) is listed as critically endangered and is now restricted to Andros, a single island complex in The Bahamas. We investigated this species' habitat use and produced the first statistically robust estimate of population size. We conducted point counts during the Bahama Oriole's breeding season in May and June 2017, extensively surveying the northern part of North Andros over a study area covering $713 \mathrm{~km}^{2}$. Hierarchical distance sampling models estimated 1269-2765 individuals within our study area, a substantially larger population on North Andros than was indicated by the previously published estimates. Earlier studies, which disproportionately sampled anthropogenic and coppice habitats, likely underestimated this species' abundance in pine forest. We found that the Bahama Oriole is widespread, most abundant in pine forest, and not dependent on developed habitats during the breeding season. These findings provide a better outlook for the species' persistence and indicate that conserving pine forest would benefit this critically endangered species. Our results also emphasize the importance of rigorously evaluating habitat use when developing conservation plans for endangered species. Systematic population counts and statistical analyses that account for detection probability are needed for endangered and vulnerable endemic birds across the Caribbean, especially in the face of increased hurricane strength and sea level rise due to climate change.
\end{abstract}

\section{L'échantillonnage fondé sur la distance couplé à une approche hiérarchique révèle une taille de population plus élevée et une utilisation de l'habitat plus vaste chez l'Oriole des Bahamas, espèce en danger}

RÉSUMÉ. Les Caraïbes abritent plus de 20 espèces de passereaux classées par l'Union internationale pour la conservation de la nature comme vulnérables, en danger ou en danger critique d'extinction. L'Oriole des Bahamas (Icterus northropi) est classé comme en danger critique d'extinction et est désormais limité à Andros, un complexe insulaire unique des Bahamas. Nous avons étudié l'utilisation de l'habitat de cette espèce et calculé la première estimation statistiquement solide de la taille de la population. Nous avons effectué des dénombrements par points d'écoute pendant la saison de reproduction de cet oriole, en mai et juin 2017, en sillonnant la partie nord d'Andros Nord sur une aire couvrant $713 \mathrm{~km}^{2}$. Des modèles hiérarchiques à partir des dénombrements fondés sur la distance ont permis d'établir le nombre d'individus à 1 269-2 765 dans notre aire d'étude, soit une population nettement plus importante sur Andros Nord que ce qui avait été rapporté précédemment. Les études antérieures, qui ont échantillonné de manière disproportionnée les milieux anthropiques et les taillis, ont probablement sous-estimé l'abondance de cette espèce dans les pinèdes. Nous avons constaté que l'Oriole des Bahamas est très répandu, qu'il est le plus abondant dans les pinèdes et qu'il ne dépend pas des milieux anthropiques pendant la saison de reproduction. Ces résultats donnent une meilleure perspective pour la pérennité de cette espèce en danger critique d'extinction et indiquent que la conservation des pinèdes lui serait bénéfique. Nos résultats soulignent également l'importance d'évaluer rigoureusement l'utilisation des habitats lors de l'élaboration de plans de conservation pour les espèces en danger. Des dénombrements de population systématiques et des analyses statistiques qui tiennent compte de la probabilité de détection sont nécessaires pour les oiseaux endémiques en danger et vulnérables dans l'ensemble des Caraïbes, en particulier face à la puissance accrue des ouragans et à l'élévation du niveau de la mer attribuables au changement climatique.

Key Words: Bahama Oriole; Caribbean; endangered species; island endemic; hierarchical distance sampling, Icterus northropi

\section{INTRODUCTION}

The Caribbean Archipelago is a global biodiversity hotspot (Myers et al. 2000) that harbors some of the most unique and threatened bird species in the Neotropics. Centuries of human activities have severely reduced the Caribbean's biodiversity, causing the extinction or endangerment of many endemic species (Anadón-Irizarry et al. 2012, Steadman and Franklin 2015). Across all families of Caribbean birds, 70 species are considered 
vulnerable, endangered, or critically endangered by the International Union for Conservation of Nature (IUCN 2020). Many of the region's endemic bird species are threatened by factors including invasive predators and habitat loss (AnadónIrizarry et al. 2012, Graves 2014). Basic data on population size, abundance, and habitat use are unavailable for most endemic Caribbean bird species, making it difficult to assess population trends or identify priority areas for conservation.

The Bahama Oriole (Icterus northropi), endemic to the Andros island complex in The Bahamas (Fig. 1), is an important case study for assessing population trends because of its endangered status and narrow distribution. In 2011, the IUCN listed the Bahama Oriole as critically endangered given its small numbers on Andros and multiple ecological threats (BirdLife International 2016). It formerly was also found on the island of Abaco, but was extirpated there during the 1990s (Price et al. 2011). Although the reasons for the oriole's disappearance from Abaco are unknown, habitat loss and predation by invasive species are linked to the declines of related Caribbean oriole species (Allcorn et al. 2012). Shiny Cowbirds (Molothrus bonariensis) were first documented in The Bahamas during the 1990s (Baltz 1995) and could have played a role in the decline of the Bahama Oriole on Abaco. Extensive logging of both Andros and Abaco during the mid 1900s also may have depressed population numbers on both islands during and following logging. Of the five extant bird species that are endemic to The Bahamas, the Bahama Nuthatch and the Bahama Oriole are the only ones considered critically endangered by the IUCN (BirdLife International 2016). The only population estimates for the Bahama Oriole prior to our study indicated that the entire global population consisted of at least 141 to 254 individuals (Price et al. 2011), and possibly fewer than 300 individuals (Baltz 1997).

Fig. 1. Map of Andros showing the study site on the north part of North Andros. Inset map shows position of Andros in The Bahamas.

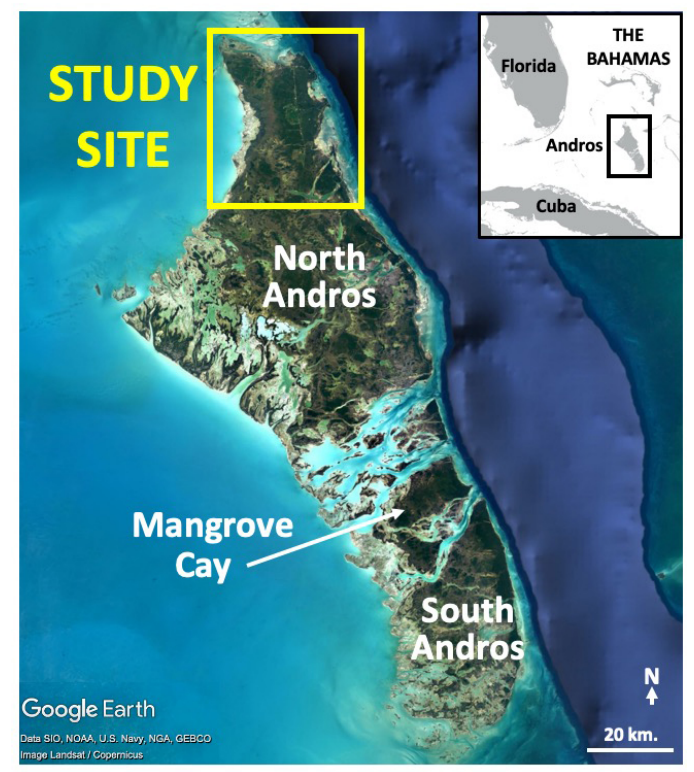

The Bahama Oriole was originally described as a distinct species (Allen 1890), then later lumped with several other Caribbean and Central American Icterus (Bond 1947). However, it was again elevated to full species status (Chesser et al. 2010) based on studies of plumage (Garrido et al. 2005, Price and Hayes 2009), song (Garrido et al. 2005), and mitochondrial DNA sequence data (Omland et al. 1999, Sturge et al. 2009). The decision to recognize the Bahama Oriole as a distinct species led to renewed scientific interest in its biology and raised concerns about its small global range (Price et al. 2011).

Accurately assessing threats to the Bahama Oriole requires a full understanding of its distribution and habitat requirements. Andros' landscape is made up of a mixture of broadleaf evergreen "coppice" forest, wetlands, anthropogenic habitats, and Caribbean pine forest. Although the Bahama Oriole is known to occur in both native forest and human-disturbed areas on Andros (Price and Hayes 2017), there is little information about its abundance in native pine forest, despite the prevalence of this habitat type on Andros. One survey conducted in February 2002 found orioles in moderate densities in mixed pine/coppice and low densities in pure coppice but did not report any orioles in pure pine forest (Currie et al. 2005). A survey conducted in July 2005 found that the orioles use both coppice and pine habitats but suggested that they occur in higher density in coppice (Price and Hayes 2017).

Previous research conducted during the breeding season suggested that this species has a close association with anthropogenic habitats such as towns and agricultural areas (Price et al. 2011). In developed areas, Bahama Orioles frequently nest in coconut palms (Cocos nucifera), an introduced species on Andros usually found near settlements or agricultural areas. Out of 46 nests recorded by Price et al. (2011), all were found in humanimpacted areas and all but five were found in coconut palms $(87 \%)$. Although some oriole pairs were also recorded nesting in native palms, suggesting at least the possibility of more widespread habitat use during the breeding season, few surveys had been conducted in pine forest. However, recent evidence demonstrated that the Bahama Oriole does nest deep in native pine forest using both pines and understory palms (Stonko et al. 2018), suggesting that its breeding range and overall abundance could be substantially larger than previous studies indicated.

Here we document breeding season habitat use of Bahama Orioles on North Andros. We used systematic point count surveys in May and June 2017, when birds were actively vocalizing and nesting. We used hierarchical distance sampling models to estimate habitat-specific abundance and oriole population size. Our goals were to: (1) develop a statistically rigorous evaluation of the species' population status, and (2) determine the full range of habitats used by the Bahama Oriole. In particular, we sought to determine whether breeding populations were present and widespread in Andros' native pine forest.

\section{METHODS}

\section{Study site}

Andros is the largest island complex in the Bahamian Archipelago (approximately $5000 \mathrm{~km}^{2}$ ). It is crossed by a series of saltwater channels that separate the land into three main subislands: North 
Andros, Mangrove Cay, and South Andros. Our study site covered an area of $713 \mathrm{~km}^{2}$ on North Andros, north of Stafford Creek (Fig. 1, all of Andros northwest of $25.240704^{\circ} \mathrm{N}, 77.920384^{\circ} \mathrm{W}$ ).

North Andros is a predominantly flat, low-lying island composed of limestone and coral rock, with extensive stands of Caribbean pine (Pinus caribaea var. bahamensis) representing the dominant native dryland vegetation (Table 1). Logging took place throughout Andros from the 1940s-1970s (Henry 1974), but timber extraction has since ceased, allowing regeneration of the native pine forest. The pine forest has a fairly open canopy, often with a dense low understory including Acacia choriophylla, Metopium toxiferum, and Tabebuia bahamensis. Thatch palms are also present, especially Leucothrinax morrisii (with more scattered Coccothrinax argentea and Sabal palmetto), and these occur in abundance in areas where the water table is high (Henry 1974).

Table 1. Area of the five habitat categories and their percent coverage ( $\%$ Total Area) in order from most common to least common on the North Andros study site. Also shown, approximate proportion of each habitat category covered by point count surveys ( $\%$ Area Surveyed).

\begin{tabular}{lccc}
\hline \hline Habitat & Area $\left(\mathrm{km}^{2}\right)$ & $\%$ Total Area & $\begin{array}{c}\% \text { Area } \\
\text { surveyed }\end{array}$ \\
\hline Pine Forest & 414.5 & $58.1 \%$ & $19.4 \%$ \\
Wetland & 233.3 & $32.7 \%$ & $2.9 \%$ \\
Coppice (Broadleaf) & 27.8 & $3.9 \%$ & $40.3 \%$ \\
Agriculture/Second Growth & 19.0 & $2.7 \%$ & $>75 \%$ \\
Developed & 18.8 & $2.6 \%$ & $65.4 \%$ \\
TOTAL & 713.4 & $100 \%$ & \\
\hline
\end{tabular}

North Andros has several other native vegetation types. Wetland habitats, including saltwater marshes and mangrove forests, are extensive on the western side of Andros, where much of the land is inundated. These wetland habitats are characterized by the presence of Rhizophora mangle, Juncus roemerianus, and Conocarpus erectus (Smith and Vankat 1992). In the transitional areas between pine forest and saltwater marshland, open savannas dominated by sawgrass (Cladium jamaicensis) are found scattered with clusters of thatch palms (Smith and Vankat 1992). Broadleaf "coppice" vegetation, common along the eastern coast, is dominated by a mixture of dry forest, broadleaf species, including Metopium toxiferum, Coccoloba diversifolia, and Bursera simaruba (Smith and Vankat 1992). Coppice on Andros' elevated ridges is sometimes mixed together with emergent pine trees (Henry 1974).

Human-disturbed habitats include developed areas (residences, government offices, small businesses), agriculture, and secondgrowth vegetation (abandoned agriculture dominated by invasive woody species). Development is concentrated along the east coast and along the main highway that runs north-south through the center of our study site (Fig. 2). Coconut palms are common in developed areas, although many have recently died from a lethal yellowing disease (Currie et al. 2005, Price et al. 2011). Agricultural areas mostly are vegetable row crops, and these are concentrated in the central part of our study site (Fig. 2). Abandoned agricultural fields and citrus orchards are frequently overtaken by invasive second growth including dense stands of
Brazilian pepper (Schinus terebinthifolia) and umbrella tree (Schefflera actinophylla).

Fig. 2. Classification of terrestrial habitats and point count locations in our study site in North Andros. Points are shown as "Detection" when at least one oriole was observed during the count. Note that we did have some detections in developed areas in the center and northeast parts of the study site; however, most detections were in pine forest including in remote forests in the south and west.

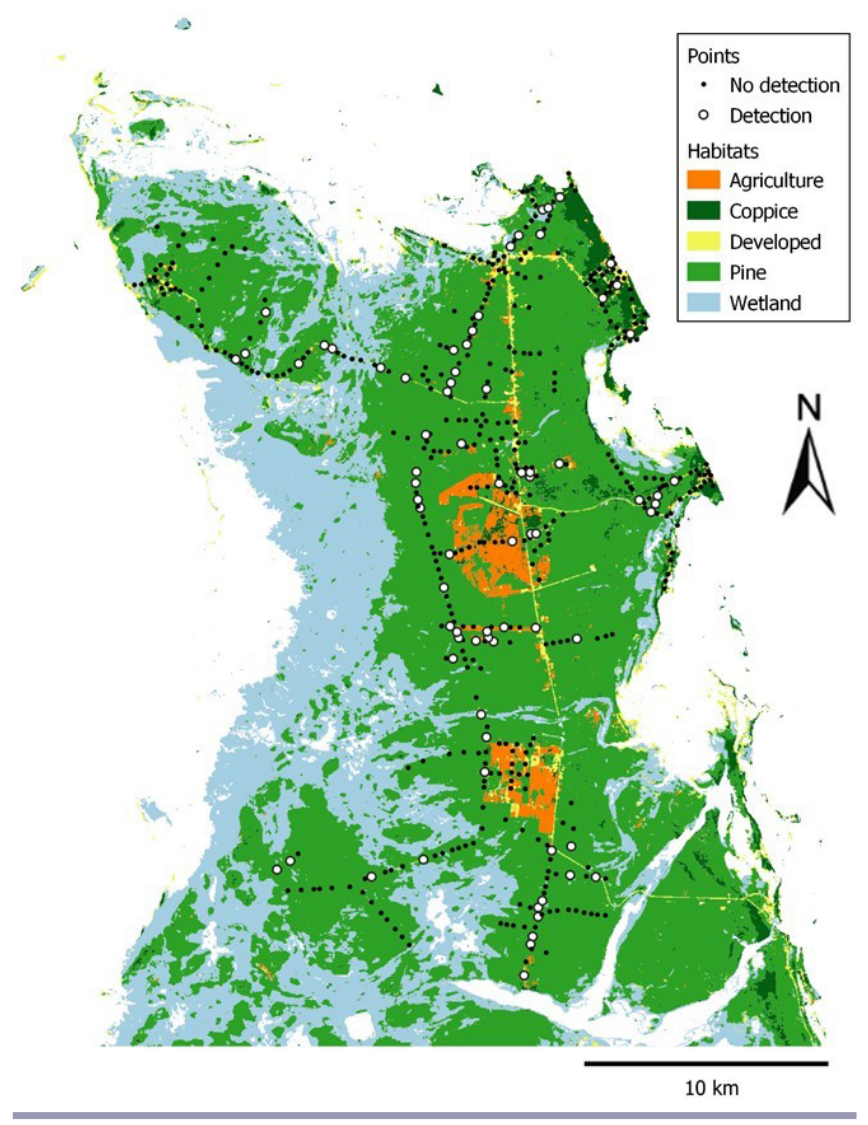

\section{Survey Design}

We established point count locations along a network of secondary roads and abandoned logging roads throughout the study area. We placed count locations on roads rather than within contiguous habitat because the challenging terrain and often dense understory of poisonwood (Metopium toxiferum) would have made it impossible to complete the large number of counts needed to estimate population size. Placing points along roads introduces the potential for certain biases, including nonrandom oriole occurrence with respect to roads, as well as biases in habitat sampling (e.g., roads are less likely to cross wetlands) (Keller and Fuller 1995). To minimize these biases, we limited our points to small and infrequently traversed roads (frequently unpaved abandoned logging roads) with little or no vehicular traffic. We used freely available moderate and high-resolution satellite imagery (Google Earth 2015, Landsat 8) in combination with QGIS to digitize minor roads and old logging roads (QGIS Development Team 2016). We then randomly placed points at a 
minimum distance of $100 \mathrm{~m}$ apart along these roads, resulting in 467 point count locations. Although most points were much farther away from their nearest neighbor (mean $=333.8 \mathrm{~m} \pm 145.8$ $\mathrm{sd}$ ), a minimum distance of $100 \mathrm{~m}$ allowed adequate representation of relatively uncommon habitats (e.g., developed and coppice).

We surveyed Bahama Orioles from 2 May-16 June 2017, visiting roughly 10 points per morning between 6:00 AM and 10:00 AM. We did not conduct counts during rain or when winds were higher than about $15 \mathrm{~km} / \mathrm{h}$. To minimize spatial and temporal biases in counts, points were given consecutive identification numbers: odd-numbered points were visited earlier in the season than evennumbered points. This approach ensured that different regions of the study site were visited repeatedly under different weather conditions and accounted for potential seasonal changes in detectability (Bibby et al. 1998). We visited each point once and visually estimated the proportion of land covered by each of the five habitat categories within $100 \mathrm{~m}$ of the observer. Each 9-min point count was subdivided into 3-min intervals to allow for estimation of availability (i.e., if an oriole sang throughout all three intervals, we counted it as one detection in each interval; Chandler et al. 2011). Following a distance sampling design (Buckland et al. 2001, 2004), we recorded the distance to all Bahama Orioles seen or heard and noted whether the detection was aural, visual, or both. For all visually detected birds, we recorded the distance from the observer using a laser rangefinder. For birds that were detected by vocalization only, we estimated distance from the observer by ear. All observers were experienced in identifying Bahama Orioles by sight and by sound.

\section{Habitat Mapping}

We downloaded Landsat 8 multispectral satellite images of Andros; these multispectral data show reflectance data from different ranges of electromagnetic wavelengths corresponding to different features of the landscape (Bleyhl et al. 2017). We conducted ground surveys across our study site to record 400 GPS locations for known habitats (habitat reference points) for the five habitat types. These points were used to train our habitat classifications and to ground-truth their accuracy. We determined the unique spectral signature of each habitat class, as defined by the habitat reference points and Landsat data. We used Random Forest classification in $\mathrm{R}$ (randomForest package; R Core Team 2019), a machine learning process that predicted the most likely habitat category of each $30 \mathrm{~m}^{2}$ pixel across the study site (for general approach see Fagan et al. 2013). Using the resulting land cover map, we calculated the percentage of the study area covered by the five most abundant habitats: pine forest, coppice, developed, agriculture, and wetland. These values were used as covariates in analyses of oriole population size at the scale of the full study site.

\section{Statistical Methods}

We used a hierarchical distance sampling (HDS) model (Chandler et al. 2011, Sillett et al. 2012) to estimate habitat-specific abundance and population size of the Bahama Oriole on the North Andros study site. Conventional distance sampling (Buckland et al. 2001) estimates abundance and accounts for imperfect detection by quantifying detection probability. Hierarchical distance sampling allows for habitat-specific estimates of three parameters: abundance, detection probability, and availability. Animals can vary in their availability for detection among replicate counts either because they temporarily emigrate from a count area or because they fail to vocalize when they are within detection range (Chandler et al. 2011, Fiske and Chandler 2011). Because Bahama Orioles are mobile and may enter or leave a given area during the survey period, we must assume that each survey area is geographically open. In addition, rare or endangered species, such as the Bahama Oriole, may reduce rates of vocalization at low densities (Mackenzie et al. 2006). Fitting models with the availability parameter is therefore important for estimating the population size of this species. We used program $\mathrm{R}$ (R Core Team 2019) and the package unmarked (Fiske and Chandler 2011) for population size analyses.

Following the methods of Sillett et al. (2012), our HDS analysis began with comparing the underlying fit of the abundance and detection data to various distributions. To assess the detection function that best fit the data, we first fit intercept-only models for the uniform, half-normal, and hazard functions and compared them using Akaike's information criteria (AIC) weights $\left(\mathrm{AIC}_{w}\right)$. Although detection distances were recorded on a continuous scale, initial analyses showed a reduction in detections at very close distances and an uptick in detections further out (Fig. 3). To address this pattern, we binned detections into three distance classes for all subsequent analyses: 0-100 m, 100-200 m, and 200$300 \mathrm{~m}$ (no orioles were detected greater than $300 \mathrm{~m}$ from the observer) (Fig. 3). Using the best AIC detection function, we next assessed fit of the best abundance distribution, testing both the Poisson and negative binomial distributions on intercept-only models.

Fig. 3. Distributions of oriole detection distances binned at two different scales: (a) $20 \mathrm{~m}$ and (b) $100 \mathrm{~m}$.
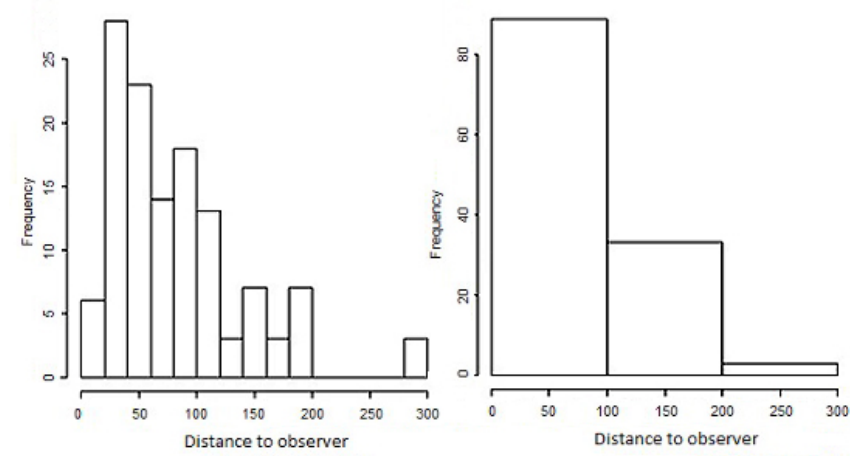

As so little is documented about the Bahama Oriole's habitat associations, we assembled a candidate model set using an exploratory approach that allowed us to consider each habitat equally as potential factors for each model parameter. The candidate model set included a total of 31 models: one null model, 15 linear single-covariate models (representing each habitat category predicting variation in either abundance, detection, or availability), five quadratic single-covariate models (representing each habitat category predicting variation in just abundance), and 
ten multivariate models assembled from combining the effects of high-scoring models (assessed using $\mathrm{AIC}_{w}$ ). We ranked each model in the candidate set using AIC and identified those with $\Delta$ AIC values $>2$.

To assess the goodness of fit of the AIC best model, we used parametric bootstrapping to generate 100 replicate data sets and compared them to the original data with the Freeman-Tukey Statistic (Brooks et al. 2000). The proportion of samples where discrepancies in the observed data exceed those of the replicate data should be $>0.05$ when model fit is adequate. To account for differences in parameter estimates among the top models, we averaged models with $\triangle \mathrm{AIC}$ values $<2$. However, due to limitations of model averaging, we could not include the two top AIC models that contained quadratic terms for pine. Model averaging was therefore done over only linear effects models.

To estimate total population size in the North Andros study site, we applied a grid of 9105 9-ha cells to our habitat classification map and used the best-fitting model to calculate Bahama Oriole abundance values based on the habitat cover in each cell. We then summed the abundance values for each cell. The final estimate of population size and a bootstrapped $95 \%$ confidence interval were generated from 1000 replicate data sets.

\section{RESULTS}

We recorded a total of 125 oriole detections across 75 of the 467 point counts ( $16 \%$ of counts) with detections in all of the five habitat types (Table 2). We recorded birds in all parts of the study site, including at many points in pine forests in the south and west of the study site far from developed areas. Furthermore, the results of the modeling detailed below indicated that the amount of pine forest was the strongest predictor of oriole abundance.

Table 2. Oriole point count summaries across habitat categories. Points were categorized according to their most abundant habitat type within a $100-\mathrm{m}$ radius. (Habitats in order of total land area following Table 1.)

\begin{tabular}{lccc}
\hline \hline Habitat & Total \# Points & $\begin{array}{c}\text { \# Points With } \\
\text { Orioles }\end{array}$ & $\begin{array}{c}\text { Points With } \\
\text { Orioles }\end{array}$ \\
\hline Pine Forest & 288 & 58 & $20 \%$ \\
Wetlands & 24 & 6 & $25 \%$ \\
Coppice & 40 & 2 & $5 \%$ \\
Agriculture & 71 & 4 & $6 \%$ \\
Developed & 44 & 5 & $11 \%$ \\
TOTAL & 467 & 75 & $16 \%$ \\
\hline
\end{tabular}

Comparison of intercept-only models revealed that oriole detection best followed a hazard-rate distribution $\left(\mathrm{AIC}_{w}=1.00\right)$. This distribution suggests that detection probability remained relatively consistent across short distances and declined at longer distances. Oriole abundance fit best to a negative binomial distribution $\left(\mathrm{AIC}_{w}=0.99\right)$, indicating considerable spatial variation in oriole abundance. As a result, we fit the candidate model set with land cover covariates by using a hazard-rate detection function and negative binomial abundance distribution.

Of the 31 candidate models considered, the best included pine forest as a linear effect on both mean oriole abundance and detection probability and accounted for $14 \%$ of the total AIC weight (Table 3; Fig. 4). Six other models fell within two AIC units of the best model and together accounted for $71 \%$ of the AIC weight. All seven of these models included pine forest as either a linear or quadratic effect on abundance. All but two models included pine forest as a covariate for detection probability, and one model included coppice as a covariate for abundance. Modelaveraged estimates of the top AIC models indicated that oriole abundance was higher at counts with extensive pine forest and that detection probability in pine forest declined beyond $75 \mathrm{~m}$ (Append. 1). Two of the models included covariates affecting oriole availability, although confidence intervals were large relative to point estimates and included 0 in two models (in which agriculture and development were included as availability covariates; Append. 2). This suggests that oriole availability did not vary substantially across the three count intervals and that habitat type did not have a strong effect on availability for detection.

Fig. 4. Functions describing the magnitude of the effect of pine cover from the best-scoring model on: (a) Bahama Oriole abundance (with standard error) and (b) Bahama Oriole detection probability. Detection functions are shown for the $25 \mathrm{th}, 50 \mathrm{th}$, and $75 \mathrm{th}$ percentiles of pine cover within point count locations.
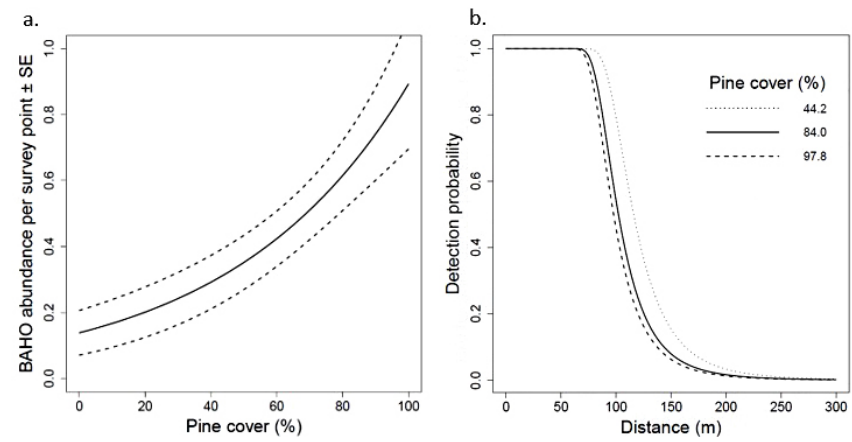

The bootstrap function in package unmarked used to estimate population size does not permit model averaged parameter estimates. We therefore used the best AIC model that contained a linear effect of pine cover on abundance to predict oriole population size on the study area. Based on the Freeman-Tukey goodness of fit statistic $(P=0.44)$, this model provided an adequate fit to the data. Applying abundance covariate values to each cell in the habitat classification map, we estimated the study site-wide population size of the Bahama Oriole to be 1790 (12692765; 95\% bootstrapped CI).

\section{DISCUSSION}

\section{Bahama Oriole Habitat Use}

The restricted global population of the Bahama Oriole has raised concerns that the species may be under imminent threat of extinction, with previous estimates suggesting a population size of fewer than 300 individuals (Baltz 1997, Price et al. 2011, BirdLife International 2016). Results of our distance sampling analysis indicate that a far larger population occurs on North Andros than was thought, and that the species is found in a wide 
Table 3. Candidate models and their associated number of parameters (K), AIC values, difference in AIC value between models $(\triangle \mathrm{AIC}), \mathrm{AIC}$ weight $(\mathrm{AICW})$ and the cumulative AIC weight of each model (cAICw). Models include covariates on oriole abundance $(\lambda)$, availability $(\Phi)$, and detection $(\pi)$. Covariates with a superscript $2\left({ }^{2}\right)$ follow a quadratic function. All models use hazard-rate detection functions and negative binomial abundance mixtures. Models within two AIC units of the highest-ranked model are shown in bold text.

\begin{tabular}{|c|c|c|c|c|c|}
\hline Model Name & $\mathbf{K}$ & AIC & $\Delta \mathrm{AIC}$ & $\mathrm{AIC}_{\mathrm{w}}$ & cAIC \\
\hline$\overline{\lambda(\text { Pine }) \Phi(.) \pi(\text { Pine })}$ & 7 & 932.25 & 0.00 & 0.14 & 0.14 \\
\hline$\lambda($ Pine $) \Phi($ Pine $) \pi$ (Pine) & 8 & 932.54 & 0.29 & 0.13 & 0.27 \\
\hline$\lambda\left(\right.$ Pine $\left.^{2}\right) \Phi(.) \pi($ Pine $)$ & 8 & 932.67 & 0.42 & 0.12 & 0.39 \\
\hline$\lambda($ Pine $) \Phi($ Dev $) \pi$ (Pine) & 8 & 932.89 & 0.64 & 0.11 & 0.49 \\
\hline$\lambda($ Pine $) \Phi(.) \pi()$. & 6 & 933.19 & 0.94 & 0.09 & 0.58 \\
\hline$\lambda\left(\right.$ Pine $\left.^{2}\right) \Phi(.) \pi()$. & 7 & 933.72 & 1.47 & 0.07 & 0.65 \\
\hline$\lambda($ Pine + Coppice $) \Phi(.) \pi($ Pine $)$ & 8 & 934.19 & 1.95 & 0.05 & 0.71 \\
\hline$\lambda$ (Pine) $\Phi($ Agriculture $) \pi($ Pine $)$ & 8 & 934.25 & 2.00 & 0.05 & 0.76 \\
\hline$\lambda\left(\right.$ Pine $\left.^{2}\right) \Phi(.) \pi$ (Wetland) & 7 & 935.14 & 2.90 & 0.03 & 0.80 \\
\hline$\lambda($ Pine + Coppice $) \Phi(.) \pi()$. & 7 & 935.16 & 2.91 & 0.03 & 0.83 \\
\hline$\lambda$ (Pine) $\Phi($ Agriculture $) \pi()$. & 7 & 935.19 & 2.94 & 0.03 & 0.86 \\
\hline$\lambda($ Pine $) \Phi($ Dev $) \pi()$. & 7 & 935.19 & 2.94 & 0.03 & 0.90 \\
\hline$\lambda(.) \Phi($ Agriculture $) \pi()$. & 6 & 936.46 & 4.21 & 0.02 & 0.91 \\
\hline$\lambda(.) \Phi($ Development $) \pi()$. & 6 & 936.46 & 4.21 & 0.02 & 0.93 \\
\hline$\lambda($ Coppice $) \Phi(.) \pi()$. & 6 & 936.67 & 4.42 & 0.02 & 0.95 \\
\hline$\lambda(.) \Phi($ Pine $) \pi()$. & 6 & 937.92 & 5.67 & 0.01 & 0.96 \\
\hline$\lambda(.) \Phi($ Wetland $) \pi()$. & 6 & 938.21 & 5.96 & 0.01 & 0.96 \\
\hline$\lambda\left(\right.$ Coppice $\left.^{2}\right) \Phi(.) \pi()$. & 7 & 938.40 & 6.15 & 0.01 & 0.97 \\
\hline$\lambda$ (Developed) $\Phi(.) \pi()$. & 6 & 938.83 & 6.58 & 0.01 & 0.98 \\
\hline$\lambda(.) \Phi(.) \pi()$. & 5 & 939.27 & 7.03 & 0.00 & 0.98 \\
\hline$\lambda\left(\right.$ Developed $\left.^{2}\right) \Phi(.) \pi()$. & 7 & 940.00 & 7.75 & 0.00 & 0.98 \\
\hline$\lambda(.) \Phi($ Coppice $) \pi()$. & 6 & 940.21 & 7.97 & 0.00 & 0.99 \\
\hline$\lambda$ (Agriculture) $\Phi(.) \pi()$. & 6 & 940.26 & 8.01 & 0.00 & 0.99 \\
\hline$\lambda$ (Wetland) $\Phi(.) \pi()$. & 6 & 940.78 & 8.53 & 0.00 & 0.99 \\
\hline$\lambda(.) \Phi(.) \pi$ (Pine) & 6 & 940.99 & 8.74 & 0.00 & 0.99 \\
\hline$\lambda(.) \Phi(.) \pi($ Wetland $)$ & 6 & 941.16 & 8.91 & 0.00 & 0.99 \\
\hline$\lambda(.) \Phi(.) \pi$ (Agriculture) & 6 & 941.20 & 8.95 & 0.00 & 1.00 \\
\hline$\lambda(.) \Phi(.) \pi($ Coppice $)$ & 6 & 941.21 & 8.96 & 0.00 & 1.00 \\
\hline$\lambda(.) \Phi(.) \pi($ Developed $)$ & 6 & 941.24 & 8.99 & 0.00 & 1.00 \\
\hline$\lambda\left(\right.$ Agriculture $\left.^{2}\right) \Phi(.) \pi()$. & 7 & 942.25 & 10.00 & 0.00 & 1.00 \\
\hline
\end{tabular}

range of habitats during the breeding season. Contrary to previous studies (Currie et al. 2005, Price and Hayes 2017), we found no evidence that Bahama Oriole abundance is lower in pine forest than other habitats. We regularly detected orioles in all five habitat types surveyed, but pine forest area was the strongest predictor of which points had oriole detections.

Our results contradict the hypothesis that the Bahama Oriole is solely reliant on either anthropogenic or coppice habitats during the breeding season, emphasizing the critical importance of pine forest for this species: 58 of the 75 points where we detected orioles were in pine forest. Importantly, orioles also frequently nest in the pine forest, using both thatch palms and Caribbean pines (Stonko et al. 2018, Yancy et al. 2020). We hypothesize that the majority of Bahama Orioles occur in pine forests, at least during the breeding season.

Bahama Orioles were also relatively abundant in wetland sites ( $25 \%$ of points had orioles), although we only sampled 24 wetland points, and these were generally mixed with or adjacent to pine forest. In 2018, we conducted preliminary point counts in different types of wetlands that suggest low densities of orioles in sawgrass and scattered mangroves, but very high densities of orioles in rare Sabal palmetto stands along the west coast (MGR, unpublished data). In addition, there are scattered records of Bahama Orioles in the wetlands of far western Andros (e.g., eBird 2020; also see
Allen 1890, Price et al. 2011). More work is needed to map and conduct point counts in the different types of wetland habitats on Andros as some wetlands could also be important habitats for orioles.

Our habitat classification scheme differed somewhat from those used in previous surveys, and any further comparison of habitatspecific abundance should account for these differences in habitat classification. Currie et al. (2005) excluded developed habitat entirely, defined three separate pine forest categories based on differences in understory, and defined two coppice categories based on canopy height. Price et al. (2011) excluded wetland from their preliminary surveys and defined "anthropogenic" habitat as including both developed and agricultural habitats. Despite these methodological differences, habitat types on Andros are fairly distinct, so our results should remain easily interpretable in the context of other studies.

\section{Population Size}

Our population estimate for the study site alone of 1269-2765 orioles far exceeds the previous estimate for the entire island of Andros, implying either an underestimation of the species' population size in prior estimates or a rapid population increase over the course of 10 years (Price et al. 2011). Considering the extensive regeneration of pine forest that has taken place since 
logging ended in the 1970s, it is possible that the oriole population is recovering from a bottleneck as the forest returns. However, the discrepancy between our results and the previous estimate likely is a result of differences in methodology. The population estimate by Price et al. (2011) did not use systematic point counts and was not designed to fully sample all habitat types. Using a hierarchical distance sampling approach ensured that we were able to sample the diversity of habitats on Andros and account for variation in oriole detectability in our population size estimate. Additionally, conducting auditory surveys in the breeding season allowed us to record individuals that escaped visual detection (over $70 \%$ of detections were auditory), which is particularly important in forest habitats.

\section{Limitations}

Although our study represents a significant improvement in our understanding of this species' population, it was still subject to several potential sources of error. Accurately estimating population densities with distance sampling requires several assumptions to be met (Buckland et al. 2001), including the assumption that birds are detected at their original location without movement caused by the observer. Movement of birds toward or away from the observer can reduce both detection and abundance estimates, especially if movement occurs immediately prior to the initial detection distance. Bahama Orioles are less wary of humans than many species, so biases due to evasive movement were likely minimal. Inaccurate estimates of distances to birds, especially for those detected only by vocalizations, could have biased our estimates in either direction. However, binning detection distances into 100-m categories likely mitigated some sources of error, including rounding distance estimates in the field (Buckland et al. 2001, 2015). Unequal detection probabilities between visual and auditory detection types may have potentially biased our detection estimates, as most detections were solely auditory (with $68 \%$ only auditory, $19 \%$ only visual, and $12 \%$ both). Habitat type may have also influenced the mode of detection, as more dense habitats (such as pine forest and coppice) may have been more likely to inhibit visual sightings than auditory detections. Unequal detection probabilities between the sexes could also have potentially biased our abundance estimates. If females were less vocal, for instance, then our population estimates could have underestimated true population size. Female Bahama Orioles do sing (Lee 2011), but knowing the rates of vocalizations of the two sexes at different times of year would help reduce sampling bias and improve our estimates.

Subdividing each point count into three consecutive 3-min survey intervals allowed us to account for heterogeneity in Bahama Oriole availability for detection caused by temporary emigration out of the survey plot or changes in song frequency during the 9min count. However, our estimates of availability did not account for potential seasonal availability across the duration of the field season (e.g., due to long-term shifts in territory placement). Seasonal changes in availability for detection may have resulted in some birds being double-counted as nearby point counts were conducted at different times in the season.

Our decision to conduct surveys along roads, while necessary to achieve an adequate number of sample points, may have influenced our abundance estimates. This possibility is especially likely where roads present a strong discontinuity with the surrounding habitat or where species display an affinity for roadside habitat (Hanowski and Niemi 1995, Rotenberry and Knick 1995). However, most of the roads we used have received little or no use since timber production ceased in the late 1960s (Henry 1974) and were overgrown, thus causing little or no discontinuity in the habitat. Furthermore, orioles did not seem to display any affinity or avoidance to roads or their edges. Conducting surveys on roads also limited the uniformity of our sampling effort, although placing sample points in a totally random or grid pattern would have presented major logistical difficulties given the extremely remote and difficult terrain. Despite our efforts to limit spatial autocorrelation by spacing out point locations, the lack of uniform stratification of roads may have caused some points to have similar oriole detection rates due to their relative proximity to each other.

\section{Conservation Implications}

Understanding the population size and habitat requirements of endangered taxa is essential for developing effective conservation strategies. Without baseline data, it is impossible to evaluate the success of conservation measures or to assign species to an appropriate IUCN Red List category. Our findings indicate that the one remaining population on Andros is much larger than previously estimated and has a breeding distribution extending across multiple habitat types. Although current guidelines suggest that protecting native coppice forest and coconut palms in anthropogenic habitat is most critical to the survival of the species (BirdLife International 2016), our results demonstrate the importance of preserving Andros' native pine forests. The majority of the oriole population likely breeds in pine forest, and the orioles frequently choose to nest in or near tall Key thatch palms (Leucothrinax morrisii; Yancy et al. 2020). Thus, conserving large tracts of pine forest, especially those with tall thatch palm in the understory, should be a priority.

The Bahama Oriole's recent extirpation from Abaco serves as a reminder that, like other members of its genus, this species is vulnerable to declines. Suspected declines have been reported for other Antillean oriole species, including the Montserrat Oriole (Icterus oberi) and the Martinique Oriole (Icterus bonana), which are both listed as vulnerable by the IUCN. Furthermore, the Saint Lucia Oriole (Icterus laudabilis) was just listed as endangered by the IUCN. These species may have suffered declines due to some of the same threats that face the Bahama Oriole, including cowbird parasitism (Lovette et al. 1999). Although Shiny Cowbirds have been observed on Andros (Baltz 1996) and have been recorded parasitizing Bahama Oriole nests in anthropogenic habitats (Price et al. 2011; KEO, unpublished data), cowbird observations in other habitats remain sparse (Price and Hayes 2017; KEO, unpublished data).

In the long term, sea level rise along with hurricane storm surges could inundate much of western Andros, thus significantly decreasing the size of the island and the amount of available pine forest habitat. Natural disasters can take a large toll on small island populations, as occurred when the Montserrat Oriole lost much of its habitat to a volcanic eruption (Hilton et al. 2003). Salt water inundation due to past hurricanes has already destroyed large portions of the pine forests on Grand Bahama ( $\mathrm{Z}$. McKenzie, personal communication), and more recently, Hurricane Dorian has affected yet more pine forest on Abaco and 
Grand Bahama. The Bahama Oriole remains particularly vulnerable to threats from hurricanes (see Wiley and Wunderle 1993), which are predicted to continue increasing in strength due to warming ocean temperatures (Webster et al. 2005).

\section{Future Directions}

To fully understand the status of the Bahama Oriole, future research should address the many remaining unknowns for this understudied species. More work is needed to determine nonbreeding season habitat use, including determining if pairs have year-round territories, as seems to be the case for several other tropical orioles (Odom et al. 2019). Quantifying rates of nest parasitism and predation, as well as recording annual survival and recruitment, would allow a better understanding of the threats facing this species. Extending oriole population counts to other parts of North Andros as well as Mangrove Cay and South Andros would determine whether these locations support similar oriole abundance. Pine forests in other parts of Andros are not as extensive and are much more fragmented by wetlands; however, pine forests on these southern islands are unlogged in remote areas (Lloyd and Slater 2010). Due to our current lack of data on habitat-specific abundance of orioles for the rest of Andros, a global population estimate for the Bahama Oriole was not possible in this study. However, we are currently using remote sensing to rigorously map habitats across the Andros island complex, which is a crucial next step.

To assess population trends through long-term monitoring of this species, we recommend replicating this survey on our study population regularly to detect any new threats to the Bahama Oriole (especially the impacts of hurricanes and climate change on this low-elevation island) and to measure how populations fluctuate over time. Future studies would benefit from understanding patterns of territory size and placement throughout the breeding season, as well as from replicating point counts at each site multiple times to account for heterogeneity in availability throughout the breeding season. Because this species is currently restricted to a single island complex, it should remain a conservation priority. However, the higher than expected population estimates from this study bode well for this species at least in the short term.

Responses to this article can be read online at: https://www.ace-eco.org/issues/responses.php/1775

\section{Acknowledgments:}

This project was primarily funded by grants from American Bird Conservancy, Birds Caribbean, and Mohammed Bin Zayed Species Conservation Fund. Kevin Omland, Colin Studds, and Matt Fagan are funded by an NSF International Research Experience for Students Grant (IRES - OISE-1827110). In addition, UMBC Undergraduate Research Awards and Explorers Club Youth Activity Fund grants supported Michael Rowley, Jennifer Christhilf, and Daniel Stonko, and an anonymous donation to the UMBC Foundation supported student research on Andros. Matthew Jeffery from Audubon's International Alliance Program and Melissa Price provided advice to help start the project. We thank The Bahamas Environment, Science and Technology Commission (BEST) for permits to conduct this research. UMBC students Alexis Scarseletta, Matthew Kane, Briana Yancy, and Cierra McKoy helped with fieldwork; Breanna Byrd helped with figures. Bahamas National Trust personnel including Lehron Rolle, Latia Smith, and Leslie Brace helped with our work on Andros; we also thank Zeko McKenzie. Finally, we thank Carleen and Doral Woods, Samuel Nelson, Tarran Simms, Diane Knoll, Karan and Norm Byers, Karin and Dave Barton, and many other residents of North Andros.

\section{LITERATURE CITED}

Allcorn, R. I., G. M. Hilton, C. Fenton, P. W. Atkinson, C. G. R. Bowden, G. A. L. Gray, M. Hulme, J. Madden, E. K. Mackley, and S. Oppel. 2012. Demography and breeding ecology of the critically endangered Montserrat Oriole. The Condor 114:227235. https://doi.org/10.1525/cond.2011.110033

Allen, J. A. 1890. Description of a new species of Icterus from Andros Island, Bahamas. The Auk 7:343-346. https://doi. org/10.2307/4067555

Anadón-Irizarry, V., D. C. Wege, A. Upgren, R. Young, B. Boom, Y. M. León, Y. Arias, K. Koenig, A. L. Morales, W. Burke, A. Pérez-Leroux, C. Levy, S. Koenig, L. Gape, and P. Moore. 2012. Sites for priority biodiversity conservation in the Caribbean Islands biodiversity hotspot. Journal of Threatened Taxa 04:2806-2844. https://doi.org/10.11609/JoTT.o2996.2806-44

Baltz, M. E. 1995. First records of the Shiny Cowbird (Molothrus bonariensis) in the Bahama Archipelago. The Auk 112:1039-1041. https://doi.org/10.2307/4089036

Baltz, M. E. 1996. The distribution and status of the Shiny Cowbird on Andros Island. Bahamas Journal of Science 3:2-5.

Baltz, M. E. 1997. Status of the Black-cowled Oriole (Icterus dominicensis northropi) in the Bahamas. Department of Agriculture, Nassau, The Bahamas.

Bibby, C. J., S. Marsden, M. Jones, and Expedition Advisory Centre. 1998. Bird surveys: expedition field techniques. Expedition Advisory Centre, London, UK.

BirdLife International. 2016. Icterus northropi. The IUCN Red List of Threatened Species 2016: e.T22736369A95132045. International Union for Conservation of Nature, Gland, Switzerland. https://doi.org/10.2305/IUCN.UK.2016-3.RLTS. T22736369A95132045.en

Bleyhl, B., M. Baumann, P. Griffiths, A. Heidelberg, K. Manvelyan, V. C. Radeloff, N. Zazanashvili, and T. Kuemmerle. 2017. Assessing landscape connectivity for large mammals in the Caucasus using Landsat 8 seasonal image composites. Remote Sensing of Environment 193:193-203. https://doi.org/10.1016/j. rse.2017.03.001

Bond, J. 1947. Birds of the West Indies. Macmillan, New York, New York, USA.

Brooks, S. P., E. A. Catchpole, and B. J. T. Morgan. 2000. Bayesian animal survival estimation. Statistical Science 15:357-376. https://doi.org/10.1214/ss/1009213003 
Buckland, S. T., D. R. Anderson, K. P. Burnham, J. L. Laake, D. L. Borchers, and L. Thomas. 2001. Introduction to distance sampling: estimating abundance of biological populations. Oxford University Press, Oxford, UK.

Buckland, S. T., D. R. Anderson, K. P. Burnham, J. L. Laake, D. L. Borchers, and L. Thomas. 2004. Advanced distance sampling. Oxford University Press, Oxford, UK.

Buckland, S. T., E. A. Rexstad, T. A. Marques, and C. S. Oedekoven. 2015. Distance sampling: methods and applications. Springer International Publishing, Cham, Switzerland. https:// doi.org/10.1007/978-3-319-19219-2

Chandler, R. B., J. A. Royle, and D. I. King. 2011. Inference about density and temporary emigration in unmarked populations. Ecology 92:1429-1435. https://doi.org/10.1890/10-2433.1

Chesser, R. T., R. C. Banks, F. K. Barker, C. Cicero, J. L. Dunn, A. W. Kratter, I. J. Lovette, P. C. Rasmussen, J. V. Remsen, J. D. Rising, D. F. Stotz, and K. Winker. 2010. Fifty-first supplement to the American Ornithologists' Union check-list of North American birds. The Auk 127:726-744. https://doi.org/10.1525/ auk.2010.127.3.726

Currie, D., J. M. W. Jr, D. N. Ewert, M. R. Anderson, A. Davis, and J. Turner. 2005. Habitat distribution of birds wintering in Central Andros, The Bahamas: implications for management. Caribbean Journal of Science 41:75-87.

eBird. 2020. eBird: an online database of bird distribution and abundance [web application]. eBird, Cornell Lab of Ornithology, Ithaca, New York, USA. [online] URL: http://www.ebird.org

Fagan, M. E., R. S. DeFries, S. E. Sesnie, J. P. Arroyo, W. Walker, C. Soto, R. L. Chazdon, and A. Sanchun. 2013. Land cover dynamics following a deforestation ban in northern Costa Rica. Environmental Research Letters 8: 034017. https://doi. org/10.1088/1748-9326/8/3/034017

Fiske, I., and R. Chandler. 2011. Unmarked: an $R$ package for fitting hierarchical models of wildlife occurrence and abundance. Journal of Statistical Software 43(1):1-23. https://doi. org/10.18637/jss.v043.i10

Garrido, O. H., J. W. Wiley, and A. Kirkconnell. 2005. The genus Icterus in the West Indies. Ornitologia Neotropical 16:449-470.

Google Earth. 2015, December 13. North Andros, The Bahamas. CNES/Airbus 2015, Maxar Technologies 2015, 2501'09.46" N, 7801'34.69" W.

Graves, G. R. 2014. Historical decline and probable extinction of the Jamaican Golden Swallow Tachycineta euchrysea euchrysea. Bird Conservation International 24:239-251. https://doi. org/10.1017/S095927091300035X

Hanowski, J. M., and G. J. Niemi. 1995. A comparison of onand off-road bird counts: do you need to go off road to count birds accurately? Journal of Field Ornithology 66:469-483.

Henry, P. W. T. 1974. The pine forests of The Bahamas. Land Resource Study, Land Resources Division, Ministry of Overseas Development, Surbiton, Surrey, UK.

Hilton, G. M., P. W. Atkinson, G. A. L. Gray, W. J. Arendt, and D. W. Gibbons. 2003. Rapid decline of the volcanically threatened
Montserrat oriole. Biological Conservation 111: 79-89. https:// doi.org/10.1016/S0006-3207(02)00252-5

International Union for Conservation of Nature (IUCN). 2020. The IUCN red list of threatened species. Version 2020-3. [online] URL: https://www.iucnredlist.org

Keller, C. M. E., and M. R. Fuller. 1995. Comparison of birds detected from roadside and off-road point counts in the Shenandoah National Park. Pages 111-116 in C. J. Ralph, J. R. Sauer, and S. Droege, technical editors. Monitoring bird populations by point counts. USDA Forest Service General Technical Report PWS-GTR-149. https://doi.org/https://doi. org/10.2737/psw-gtr-149

Lee, V. A. 2011. Vocalization behavior of the endangered Bahama Oriole (Icterus northropi): ontogenetic, sexual, temporal, duetting pair, and geographic variation. Thesis, Loma Linda University, Loma Linda, California, USA.

Lloyd, J. D., and G. L. Slater. 2010. Rapid ecological assessment of the avian community and their habitats on Andros, The Bahamas. Ecostudies Institute, Mount Vernon, Washington, USA.

Lovette, I. J., E. Bermingham, and R. E. Ricklefs. 1999. Mitochondrial DNA phylogeography and the conservation of endangered Lesser Antillean Icterus orioles. Conservation Biology 13:1088-1096. https://doi.org/10.1046/j.1523-1739.1999.98300.x

MacKenzie, D. I., J. D. Nichols, J. A. Royle, K. H. Pollock, L. L. Bailey, and J. E. Hines. 2006. Occupancy estimation and modeling: inferring patterns and dynamics of species occurrence. Academic Press, Burlington, Massachusetts, USA.

Myers, N., R. A. Mittermeier, C. G. Mittermeier, G. A. B. da Fonseca, and J. Kent. 2000. Biodiversity hotspots for conservation priorities. Nature 403:853-858. https://doi.org/10.1038/35002501

Odom, K. J., E. M. Rose, M. T. Hallworth, O. A. Díaz-Marrero, and K. E. Omland. 2019. Females and males maintain similarsized, stable territories between breeding and nonbreeding seasons in a tropical oriole (Icterus icterus). Wilson Journal of Ornithology 131:524-533. https://doi.org/10.1676/18-135

Omland, K. E., S. M. Lanyon, and S. J. Fritz. 1999. A molecular phylogeny of the new world orioles (Icterus): the importance of dense taxon sampling. Molecular Phylogenetics and Evolution 12:224-239. https://doi.org/10.1006/mpev.1999.0611

Price, M. R., and W. K. Hayes. 2009. Conservation taxonomy of the Greater Antillean Oriole (Icterus dominicensis): diagnosable plumage variation among allopatric populations supports species status. Journal of Caribbean Ornithology 22:19-25.

Price, M. R., and W. K. Hayes. 2017. Diverse habitat use during two life stages of the critically endangered Bahama Oriole (Icterus northropi): community structure, foraging, and social interactions. PeerJ 5: e3500. https://doi.org/10.7717/peerj.3500

Price, M. R., V. A. Lee, and W. B. Hayes. 2011. Population status, habitat dependence, and reproductive ecology of Bahama Orioles: a critically endangered synanthropic species. Journal of Field Ornithology 82:366-378. https://doi.org/10.1111/ j.1557-9263.2011.00340.x 
QGIS Development Team 2016. QGIS Geographic Information System. Open Source Geospatial Foundation Project. [online] URL: https://www.qgis.org/en/site/

R Core Team. 2019. R: a language and environment for statistical computing. R Foundation for Statistical Computing, Vienna, Austria.

Rotenberry, J. T., and S. T. Knick. 1995. Evaluation of bias in roadside point count surveys of passerines in shrubsteppe and grassland habitats in Southwestern Idaho. Pages 99-102 in C. J. Ralph, J. R. Sauer, and S. Droege, technical editors. Monitoring bird populations by point counts. USDA Forest Service General Technical Report PWS-GTR-149. https://doi.org/https://doi. org/10.2737/psw-gtr-149

Sillett, T. S., R. B. Chandler, J. A. Royle, M. Kéry, and S. A. Morrison. 2012. Hierarchical distance-sampling models to estimate population size and habitat-specific abundance of an island endemic. Ecological Applications 22:1997-2006. https:// doi.org/10.1890/11-1400.1

Smith, I. K., and J. L. Vankat. 1992. Dry evergreen forest (coppice) communities of North Andros Island, Bahamas. Bulletin of the Torrey Botanical Club 119:181-191. https://doi.org/10.2307/2997030

Steadman, D. W., and J. Franklin. 2015. Changes in a West Indian bird community since the late Pleistocene. Journal of Biogeography 42:426-438. https://doi.org/10.1111/jbi.12418

Stonko, D. C., L. E. Rolle, L. S. Smith, A. L. Scarselletta, J. L. Christhilf, M. G. Rowley, S. S. Yates, S. Cant-Woodside, L. Brace, S. B. Johnson, and K. E. Omland. 2018. New documentation of pine forest nesting by the critically endangered Bahama Oriole (Icterus northropi). The Journal of Caribbean Ornithology 31:1-5.

Sturge, R. J., F. Jacobsen, B. B. Rosensteel, R. J. Neale, and K. E. Omland. 2009. Colonization of South America from Caribbean islands confirmed by molecular phylogeny with increased taxon sampling. The Condor 111:575-579. https://doi.org/10.1525/ cond.2009.080048

Webster, P. J., G. J. Holland, J. A. Curry, and H.-R. Chang. 2005. Changes in tropical cyclone number, duration, and intensity in a warming environment. Science 309:1844-1846. https://doi. org/10.1126/science. 1116448

Wiley, J. W., and J. M. Wunderle. 1993. The effects of hurricanes on birds, with special reference to Caribbean islands. Bird Conservation International 3:319-349. https://doi.org/10.1017/ S0959270900002598

Yancy, B. M., J. M. Antalffy, M. G. Rowley, C. N. McKoy, D. C. Stonko, L. E. Rolle, J. L. Christhilf, S. B. Johnson, S. CantWoodside, and K. E. Omland. 2020. Nest site characteristics of the critically endangered Bahama Oriole (Icterus northropi).
Journal of Caribbean Ornithology 33:95-103. [online] URL: http://jco.birdscaribbean.org/index.php/jco/article/view/1242/967
Editor-in-Chief: Alexander L.Bond Subject Editor: Michael BWunder
Sponsored by the Society of Canadian Ornithologists and Birds Canada

Parrainée par la Société des ornithologistes du Canada et Oiseaux Canada

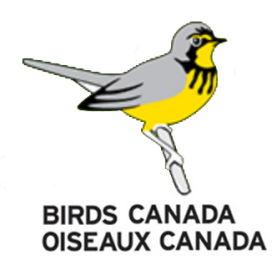


APPENDIX 1. Fig. S1. Model-averaged estimates and standard error of Bahama Oriole (a) abundance in relation to the amount of pine cover and (b) detection probability in relation to distance from observer on North Andros, Bahamas. Abundance and detection parameters were averaged over candidate models within two AIC units of the best model.

a.

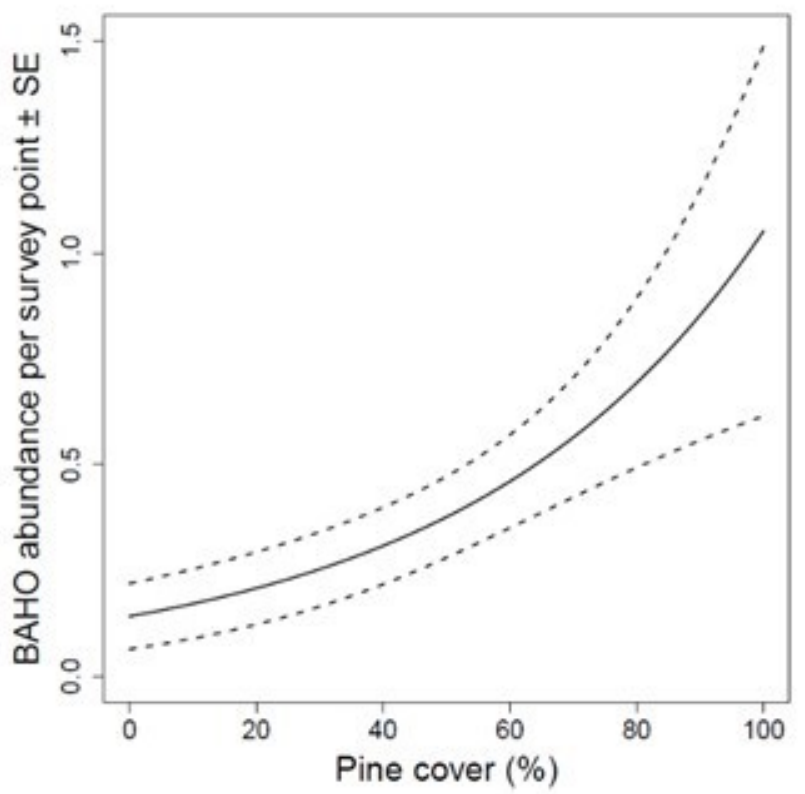

b.

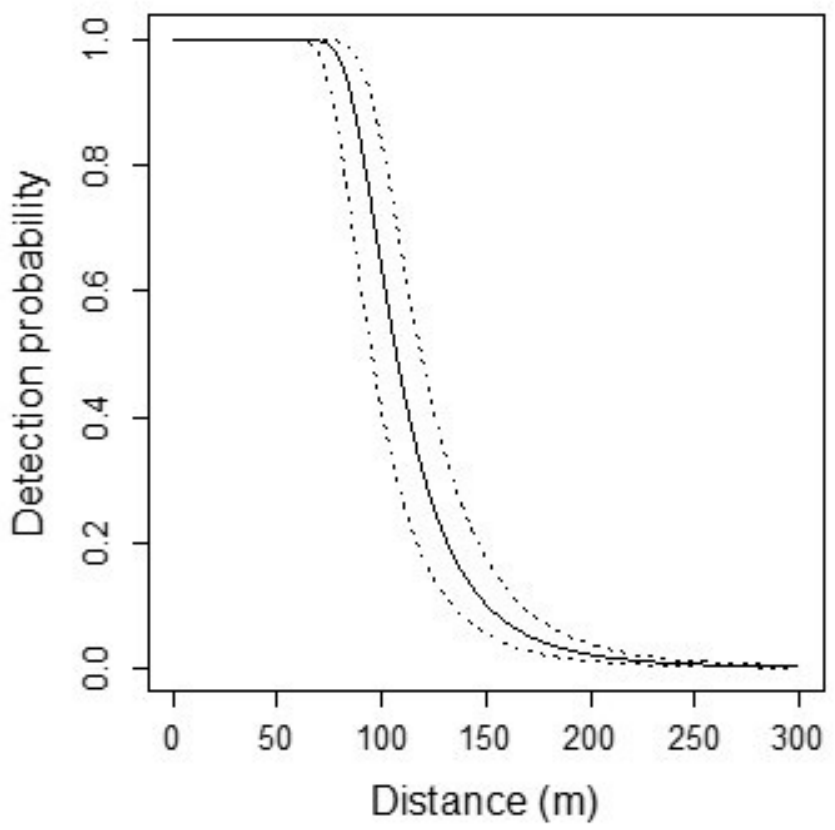


APPENDIX 2. Table S1. Parameter estimates (with standard error in parentheses) for each coefficient present across all levels (abundance, availability, and detection) for each model with $\Delta \mathrm{AIC}<2$ and the averaged model.

$\begin{array}{lll}\text { Model Name } & \text { Coefficient } & \text { Estimate (SE) } \\ \lambda(\text { Pine }) \Phi(.) \pi(\text { Pine }) & \text { Intercept } & -0.66(0.18) \\ & \text { Pine } & 0.61(0.20) \\ \lambda(\text { Pine }) \Phi(\text { Pine }) \pi(\text { Pine }) & \text { Intercept } & -0.45(0.29) \\ \lambda\left(\text { Pine }^{2}\right) \Phi(.) \pi(\text { Pine }) & \text { Pine } & 0.84(0.30) \\ & \text { Intercept } & -0.45(0.24) \\ \lambda(\text { Pine }) \Phi(\text { Dev }) \pi(\text { Pine }) & \text { Pine } & 0.46(0.23) \\ \lambda(\text { Pine }) \Phi(.) \pi(.) & \text { Pine } & -0.24(0.20) \\ & \text { Intercept } & -0.47(0.30) \\ \lambda\left(\text { Pine }^{2}\right) \Phi(.) \pi(.) & \text { Pine } & 0.76(0.25) \\ & \text { Intercept } & -0.62(0.17) \\ \lambda\left(\text { Pine }^{2}+\text { Coppice }\right) \Phi(.) \pi(\text { Pine }) & \text { Pine } & 0.41(0.15) \\ & \text { Intercept } & -0.42(0.24) \\ & \text { Pine } & 0.26(0.20) \\ \text { Averaged model } & \text { Pine } & -0.23(0.20) \\ & \text { Coppice } & -0.66(0.18) \\ & \text { Intercept } & -0.06(0.24) \\ & \text { Pine } & 0.66(0.28)\end{array}$

\begin{tabular}{|c|c|c|c|}
\hline \multicolumn{2}{|c|}{ Availability $(\Phi)$} & \multicolumn{2}{|c|}{ Detection $(\pi)$} \\
\hline \multirow[t]{3}{*}{ Coefficient } & Estimate (SE) & Coefficient & Estimate (SE) \\
\hline & $9.46(46.0)$ & Intercept & $4.60(0.09)$ \\
\hline & & Pine & $-0.10(0.07)$ \\
\hline Intercept & $4.37(4.58)$ & Intercept & $4.60(0.08)$ \\
\hline \multirow[t]{3}{*}{ Pine } & $-4.70(4.57)$ & Pine & $-0.10(0.07)$ \\
\hline & $8.71(31.3)$ & Intercept & $4.61(0.09)$ \\
\hline & & Pine & $-0.10(0.10)$ \\
\hline Intercept & $3.83(7.87)$ & Intercept & $4.61(0.09)$ \\
\hline \multirow[t]{7}{*}{ Developed } & $4.69(10.82)$ & Pine & $-0.11(0.07)$ \\
\hline & $10.6(88.2)$ & & $4.59(0.08)$ \\
\hline & $9.38(46.4)$ & & $4.60(0.08)$ \\
\hline & $10.4(75.2)$ & Intercept & $4.60(0.09)$ \\
\hline & & Pine & $-0.10(0.07)$ \\
\hline & $7.11(47.6)$ & Intercept & $4.60(0.09)$ \\
\hline & & Pine & $-0.10(0.07)$ \\
\hline
\end{tabular}

